\title{
Ecological implications of Cousinia Cass. (Asteraceae) persistence through the last two glacial-interglacial cycles in the continental Middle East for the Irano- Turanian flora
}

\author{
Morteza Djamali a,c*, Alex Baumel a, Simon Brewer ${ }^{\mathrm{b}}$, Stephen T. Jackson ${ }^{\mathrm{b}, \mathrm{c}}$, Joachim W. \\ Kadereit ${ }^{\mathrm{d}}$, Sara López-Vinyallonga ${ }^{\mathrm{e}}$, Iraj Mehregan ${ }^{\mathrm{f}}$, Esmaeil Shabanian ${ }^{\mathrm{g}}$, Aleksandra \\ Simakova \\ a Institut Méditerranéen de Biodiversité et d'Ecologie (IMBE UMR CNRS 7263), Europôle Méditerranéen de l'Arbois, \\ Bâtiment Villemin BP80, 13545 Aix-en-Provence, Cedex 04, France \\ ${ }^{b}$ Department of Botany 3165, 1000 E. University Ave., University of Wyoming, Laramie, WY 82071, USA \\ ${ }^{\circ}$ Program in Ecology, Berry Center for Biodiversity and Conservation, University of Wyoming, Laramie, WY 82071, USA \\ d Institut für Spezielle Botanik und Botanischer Garten, Johannes Gutenberg-Universität Mainz, D-55099 Mainz, \\ Germany \\ ${ }^{e}$ Botanic Institute of Barcelona (IBB-CSIC-ICUB), Pg. del Migdias. $n ., 08038$ Barcelona, Spain \\ ${ }^{f}$ Department of Biology, Faculty of Basic Sciences, Islamic Azad University, Science and Research Branch, Tehran, \\ Iran \\ ${ }^{g}$ CEREGE-UMR CNRS, Université Aix-Marseille, IRD, Collège de France, Europôle Méditerranéen de l'Arbois, BP 80 , \\ 13545 Aix-en-Provence, Cedex 04, France \\ ${ }^{n}$ Geological Institute, Russian Academy of Sciences, Pyzevskii 7, Moscow, 119017 Russia
}

\begin{abstract}
This study explores the response of the Irano-Turanian flora to Quaternary glacialinterglacial cycles in SW Asia. We use new fossil pollen data to assess variation in abundance of Cousinia Cass. (Compositae), a large genus typical for the IranoTuranian flora, during these cycles. The results are compared with modern topography, tectonic and palaeoclimatic history, and recent phylogenetic data to explain the extremely high speciation rate and level of endemism as well as the modern geographical distribution of the genus. Cousinia is consistently well-represented in glacial-age and late-glacial pollen assemblages of NW Iran and E Anatolia. In the 200,000-year pollen sequence from Lake Urmia, NW Iran, Cousinia pollen shows significant values and is nearly continuously represented during both the last glacial ( $\sim 70$ ka to Holocene) and penultimate glacial periods ( 190 to $130 \mathrm{ka}$ ). In contrast, its pollen is less frequent and occurs only sporadically during the last interglacial period and the Holocene. This pattern suggests that Cousinia could not only withstand Quaternary glaciations, but was a significant part of the glacial-age landscapes of the Irano-Turanian territory. We argue that the extremely high rate of speciation and endemism of Cousinia is due to (i) the continuous presence of a complex topography in the Middle East and Central Asia since Tertiary times, which created a wide range of environmental niches and facilitated the formation and persistence of isolated populations over long periods, (ii) relatively stable climate during the late MiocenePliocene compared to the Quaternary period that caused small species range shifts and gene flow, and (iii) a dampened impact of multiple glacial- interglacial cycles on the mountain regions of SW Asia compared to the higher latitude European mountain ranges. This left an extensive, non-glaciated altitudinal zone for the survival of IranoTuranian species, there by reducing extinction during glacial periods. During interglacial periods, many Cousinia species may have been geographically isolated in high mountain "interglacial refugia" of the Irano-Turanian region. Overall, the combination of the above factors during the Neogene resulted in geographical isolation and reduced gene flow, thereby fostering allopatric speciation in Cousinia and probably also in many other speciose Irano-Turanian plant taxa.
\end{abstract}


Key words: Cousinia, Quaternary glaciations, allopatric speciation, isolation, topographical heterogeneity, interglacial refugia, tectonic history, SW Asia

Preprint submitted to Elsevier

$1^{\text {st }}$ March 2011

\section{Introduction}

The Irano-Turanian area is one of the richest floristic regions of the world. It is located at the contact zone of the Mediterranean (W), Saharo-Sindian (S), and Euro-Siberian (N) floristic regions (Fig. 1) and is characterized by high species diversity and endemism, particularly in several large taxonomic groups including the genera Astragalus L. (Fabaceae), Cousinia Cass. (Compositae), Acantholimon Boiss. (Plumba- ginaceae), and the families Apiaceae, Brassicaceae, and Chenopodiaceae (e.g. Eig, 1931; Davis et al., 1965-1988; Guest and Al-Rawi, 1966; Zohary, 1973; Couvreur et al., 2010). The evolution and persistence of floristic richness in the face of repeated glacial/interglacial climatic cycles is of interest to biogeography and conservation. What role did glacial/interglacial cycles play in amplifying or dampening species richness in the region? Or is the modern floristic richness a legacy of Tertiary speciation events?

Responses of vegetation to the Quaternary glacial-interglacial cycles in the IranoTuranian realm have been previously described in a number of studies (van Zeist and Bottema, 1977; Bottema, 1986; Wick et al., 2003; Djamali et al., 2008a). However, none specifically examined floristic changes driven by the climatic cycles. We review late Pleistocene-Holocene pollen records from the Irano-Turanian part of the Middle East, and use a recently published long pollen record from Lake Urmia (NW Iran; Djamali et al., 2008a) to examine the responses of the Irano-Turanian flora to climatic changes during the Quaternary period. Lake Urmia is situated in one of the richest subregions of the Irano-Turanian phytogeographical region (IT2 according to White and Léonard, 1991 and Irano-Anatolian according to Zohary, 1973; Fig. 1).

One problem with this approach is that most of the dominant upland Irano-Turanian steppe plants (e.g., Astragalus, Acantholimon, Acanthophyllum Hook \& Arn., Cousinia Cass., Heliotropium L., Zygophyllaceae, etc.) and many steppe-forest trees (Amygdalus L., Prunus L., Cerasus Mill., and Pyrus L.) are entomophilous and hence are severely under-represented in the pollen rain (e.g. van Zeist et al., 1970; Moore and Stevenson, 1982; Djamali et al., 2008b). These genera are only sparsely recorded in pollen diagrams. The genus Cousinia is, however, more frequently encountered in pollen diagrams of the Irano-Turanian region (e.g. van Zeist and Bottema, 1977; Wick et al., 2003; Djamali et al., 2008a). Further, the modern geographical range of Cousinia correlates almost perfectly with the Irano-Turanian floristic region suggesting it as a good representative of the Irano-Turanian flora (Figs. 1 and 2). Chenopodiaceae comprise another characteristic Irano-Turanian group that iswell-represented in pollen diagrams. However, this pollen may belong to either littoral lowland or upland species (Djamali et al., 2008c), whereas Cousinia spp. most commonly grow in the upland vegetation. This is confirmed by the modern distribution of most Cousinia species, which are concentrated in the mountainous areas of Turkey, Iran, Afghanistan, and Central Asia (Knapp, 1987). This suggests that the variation in the pollen curves of Cousinia can be used as a proxy to understand how the Irano-Turanian upland flora in general may have responded to the Quaternary glacial-interglacial cycles. Although some studies on the pollen morphology of Cousinia exist, (Shtepa, 1976; Saber et al., 2009), current knowledge is insufficient to investigate past changes in species diversity of the genus. 


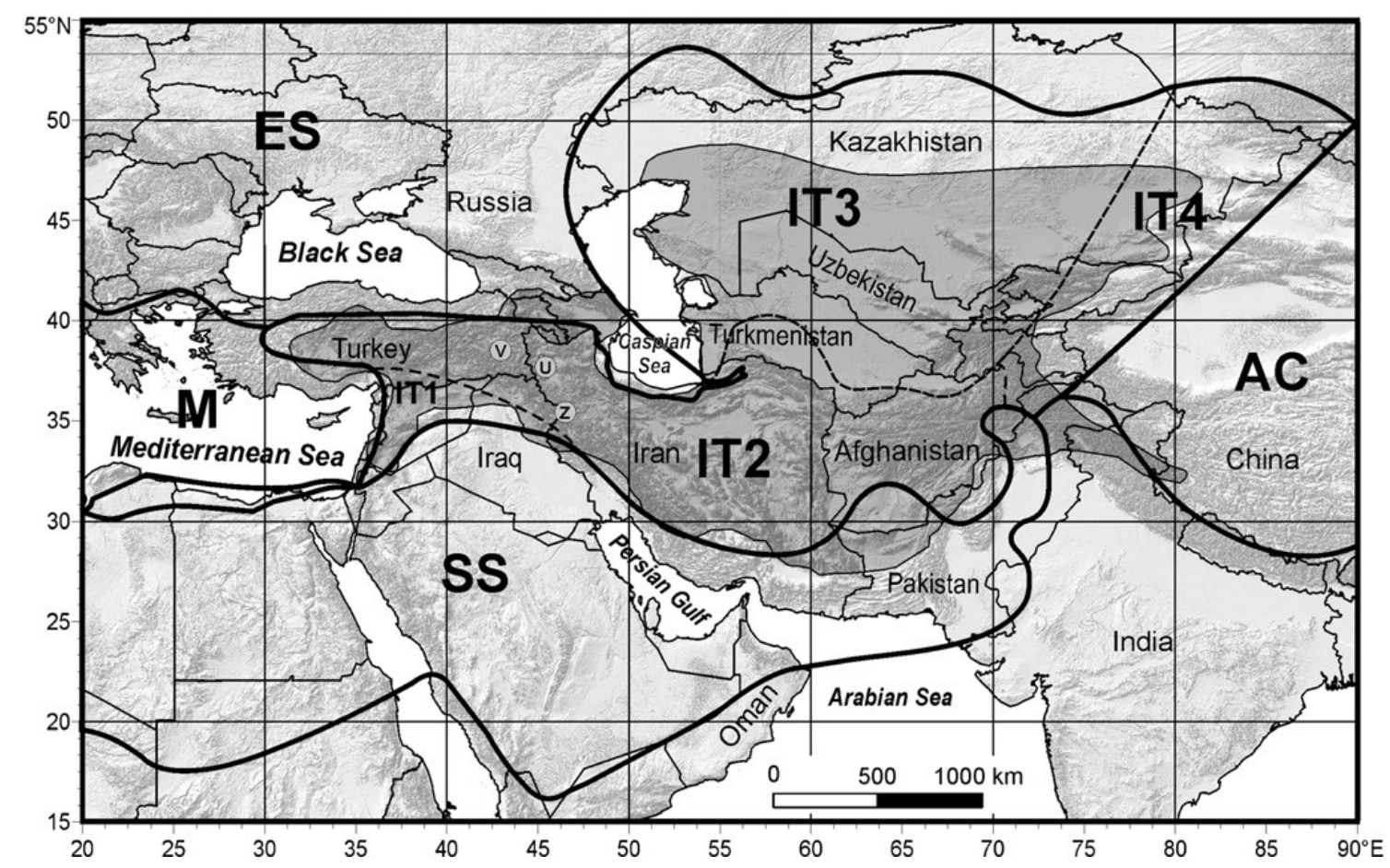

Fig. 1. Phytogeographical map of SW Asia. IT: Irano-Turanian with numbers 1 to 4 designating the four subregions proposed by White and Léonard (1991), ES: Euro-Siberian, M: Mediterranean, SS: Saharo-Sindian, AC: Central Asiatic. The geographical range of Cousinia is shown in dark gray. The three lakes referred to in the description of pollen data are indicated: V: Lake Van; U: Lake Urmia; Z: Lake Zeribar.

One problem with this approach is that most of the dominant upland Irano-Turanian steppe plants (e.g., Astragalus, Acantholimon, Acanthophyllum Hook \& Arn., Cousinia Cass., Heliotropium L., Zygophyllaceae, etc.) and many steppe-forest trees (Amygdalus L., Prunus L., Cerasus Mill., and Pyrus L.) are entomophilous and hence are severely under-represented in the pollen rain (e.g. van Zeist et al., 1970; Moore and Stevenson, 1982; Djamali et al., 2008b). These genera are only sparsely recorded in pollen diagrams. The genus Cousinia is, however, more frequently encountered in pollen diagrams of the Irano-Turanian region (e.g. van Zeist and Bottema, 1977; Wick et al., 2003; Djamali et al., 2008a). Further, the modern geographical range of Cousinia correlates almost perfectly with the Irano-Turanian floristic region suggesting it as a good representative of the Irano-Turanian flora (Figs. 1 and 2). Chenopodiaceae comprise another characteristic Irano-Turanian group that iswell-represented in pollen diagrams. However, this pollen may belong to either littoral lowland or upland species (Djamali et al., 2008c), whereas Cousinia spp. most commonly grow in the upland vegetation. This is confirmed by the modern distribution of most Cousinia species, which are concentrated in the mountainous areas of Turkey, Iran, Afghanistan, and Central Asia (Knapp, 1987). This suggests that the variation in the pollen curves of Cousinia can be used as a proxy to understand how the Irano-Turanian upland flora in general may have responded to the Quaternary glacial-interglacial cycles. Although some studies on the pollen morphology of Cousinia exist, (Shtepa, 1976; Saber et al., 2009), current knowledge is insufficient to investigate past changes in species diversity of the genus. 


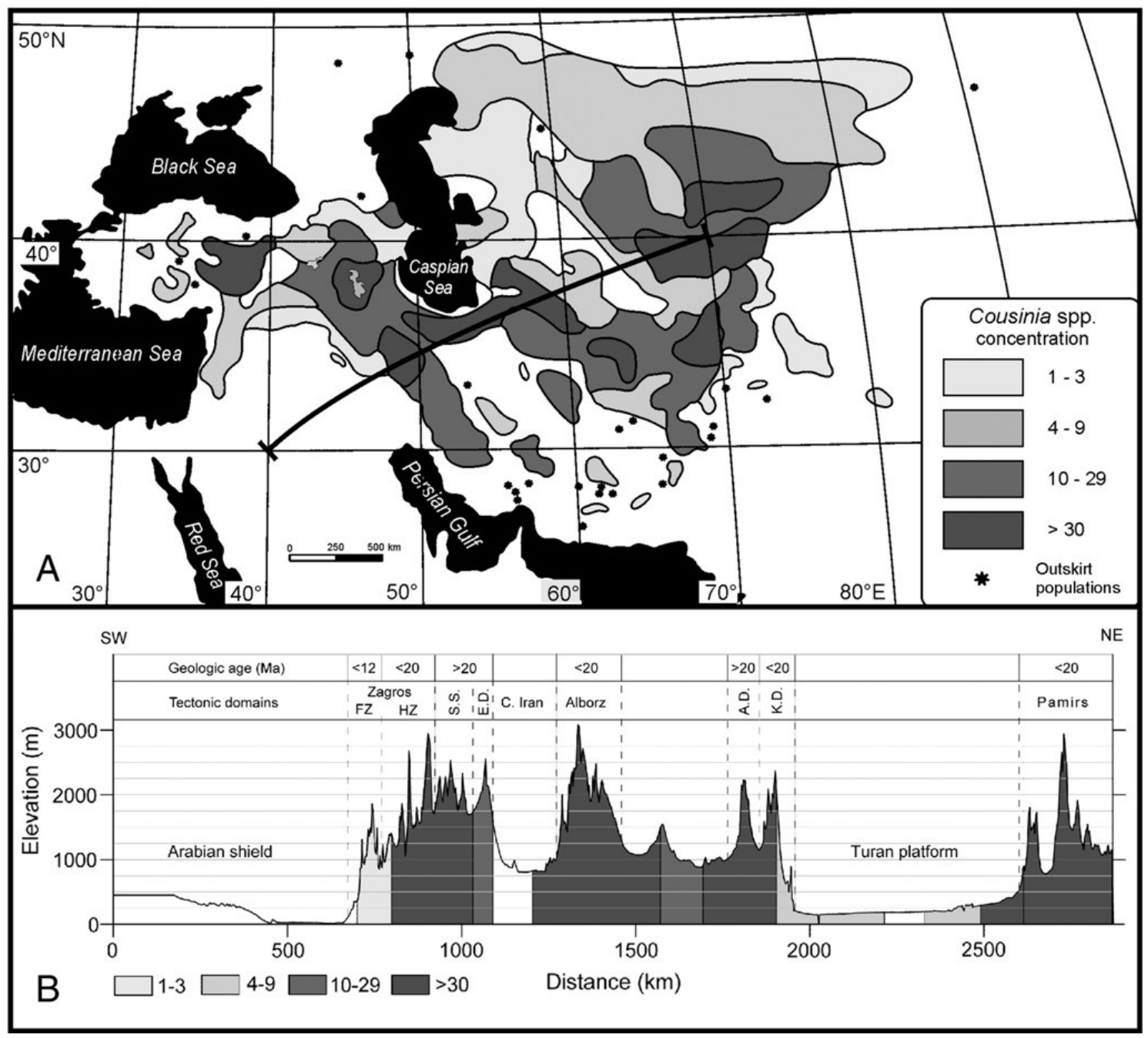

Fig. 2. A. Map showing the distribution of Cousinia species richness in SW Asia (after Knapp, 1987). B. A topographic cross section along the solid line in $\mathrm{A}\left(\right.$ from $40^{\circ} \mathrm{E}, 30^{\circ} \mathrm{N}$ to $70^{\circ} \mathrm{E}, 40^{\circ} \mathrm{N}$ ). Abbreviations are the major tectono-sedimentary units of Iran and adjacent areas: U.D., Urumieh (Urmia)-Dokhtar volcanic arc; A.D., Allah Dagh Mountains; K.D., Kopeh Dagh Mountains; C. Iran, Central Iran; S.S., Sanandaj-Sirjan; HZ, High Zagros; FZ, Folded Zagros. The topographical profile is based on GTOPO 30 digital elevation model.

This palaeoecological approach can be complemented by phylogenetic investigations to better reveal plant population changes driven by past climatic changes (e.g. Hu et al., 2008). Recent analyses of the phylogeny and systematic of the Arctium-Cousinia complex (López-Vinyallonga et al., 2009, 2011) have revealed that within this complex only Cousinia subg. Cousinia should be treated as a newly defined genus Cousinia. All pollen considered here belongs to the Cousinia-type characteristic of this lineage. These findings, combined with palaeoecological data, allow us to evaluate the factors driving the diversification of one of the most speciose taxa of the Irano-Turanian flora.

Using Cousinia as a representative taxon, this study aims at (i) reconstructing the variation in distribution and abundance of Cousinia in the Irano-Turanian landscapes of NW Iran during the two most recent glacial-interglacial cycles, (ii) analyzing the relationships between modern species diversity and distribution patterns in Cousinia and the topography of SW Asia, (iii) studying the likely role of the long-term regional tectonic history in shaping this distribution pattern, and (iv) inferring the effects of Quaternary glaciations and pre-Quaternary palaeoclimates in SW Asia on the evolution of the Irano-Turanian flora. 


\section{Material and methods}

To investigate the relationship between the distribution of Cousinia species and the topography of the Middle East and Central Asia, we analyzed the topographical heterogeneity of each of the four classes of species diversity (i.e. areas with equal number of species) of Cousinia as proposed by Knapp (1987). Fig. 2A shows the geographical distribution of these diversity areas, and Fig. 2B shows a topographical transect along with the specific diversity of Cousinia. In Fig. 3, the spatial distribution of different elevational levels corresponding to each species diversity classes (1-3 spp., 4-9 spp., 10-29 spp., >30 spp.) is shown.

We examined the changes in pollen percentages of Cousinia s. str. in the available late glacial-Holocene pollen diagrams of the continental Middle East (see Table 1, van Zeist and Bottema, 1977 Bottema and Woldring, 1984; Bottema, 1986; Woldring and Bottema, 2001/2002; Wick et al., 2003; Djamali et al., 2008a). Cousinia percentages were calculated based on pollen count data available in European Pollen Database (EPD: http://www.europeanpollendatabase.net/). Particular attention was paid to the longest of these pollen records; core $\mathrm{BH} 3$ from Lake Urmia, which covers the last two glacial-interglacial cycles (Djamali et al., 2008a). In this core, variations of trees and upland steppe plants (plants growing in well-drained soils including Poaceae but excluding aquatic and halophytic plants such as Cyperaceae, TyphaSparganium, and Chenopodiaceae) were compared to the changes in Cousinia (Fig. 5). The transition from the penultimate glacial to the last interglacial period was studied with higher resolution, compared to the Penultimate Glacial, in order to understand changes in the abundance of Cousinia during a typical glacial-interglacial transition (Termination 2). In addition to pollen percentages (calculated in Tilia software and visualized in TGView; Grimm, 2004/2005), pollen concentrations were calculated for BH3 record using Lycopodium spores as exotic markers (Stockmarr, 1971). Unfortunately, concentration values could not be calculated for the late-Pleistocene-Holocene records of lakes Zeribar, Urmia and Van based on data available in EPD.

The chronostratigraphy of the studied long pollen record of Lake Urmia is based on correlation with several terrestrial pollen and marine isotope records, together with two radiocarbon ages and one U/Th age (see Djamali et al., 2008a).

To compare the variations of pollen concentration among different plant groups during different climatic stages (Marine Isotope Stages in Fig. 5), coefficients of variation or CVs $(C V=\sigma / \mu \times 100, \sigma=s t a n d a r d$ deviation and $\mu=$ mean) were calculated using $R$ statistical software ( $R$ Development Core Team, 2010). The CV values provide an index for the stability of each taxon or plant group during a given interval, so that lower values correlate with higher stability in time during a given period. This can be used as a rough estimate for the persistence of a taxon or plant group in the landscape (Table 2).

\section{Results}

The results of our topographical analysis show a direct relationship between the heterogeneity of topography and Cousinia species diversity (Fig. 3). The highest diversity is observed in regions with the widest range of topographical variations and the highest frequency of elevations above $2000 \mathrm{~m}$ (Fig. $3 \mathrm{C}$ and D). This is demonstrated spatially in the topographical cross-section of Fig. 2 showing that the major SW Asian mountain ranges including the Zagros Mts (W Iran), Alborz Mts ( N Iran), Kopeh Dagh Mts (NE Iran), and parts of the high plateau of Pamir contain the highest Cousinia species richness. 
A

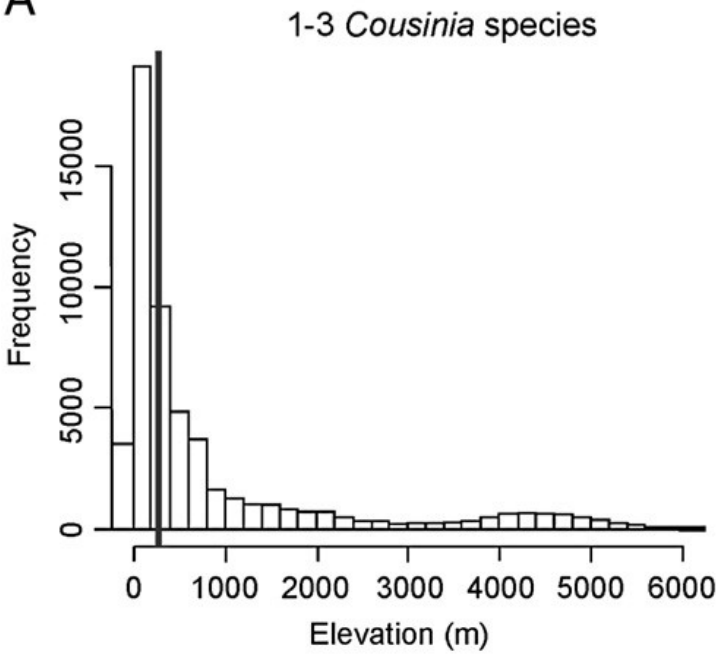

C

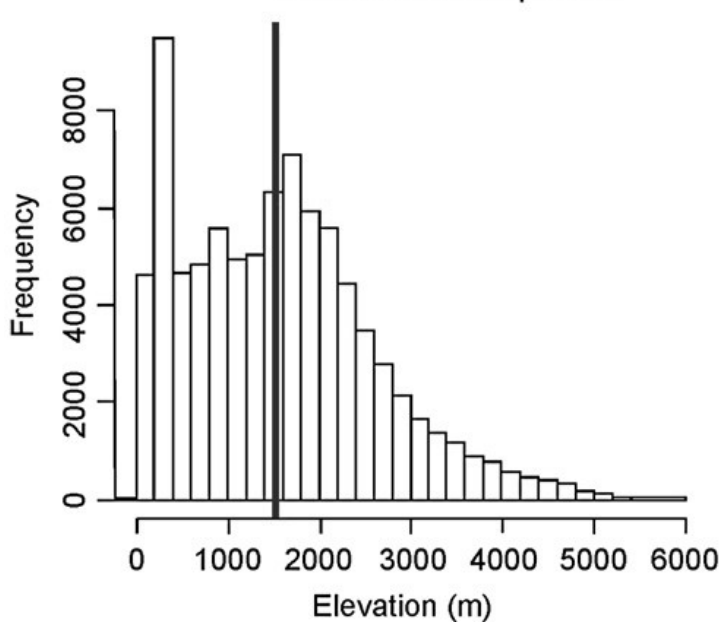

B

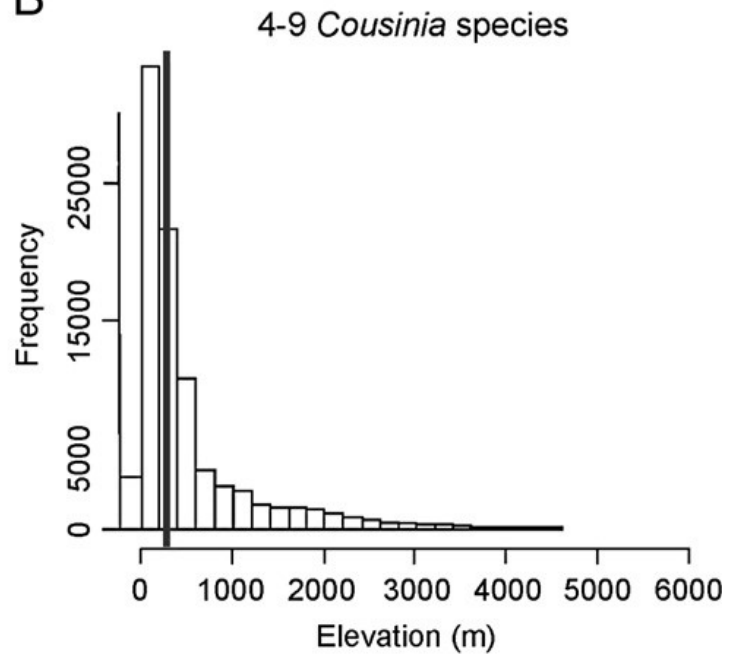

D

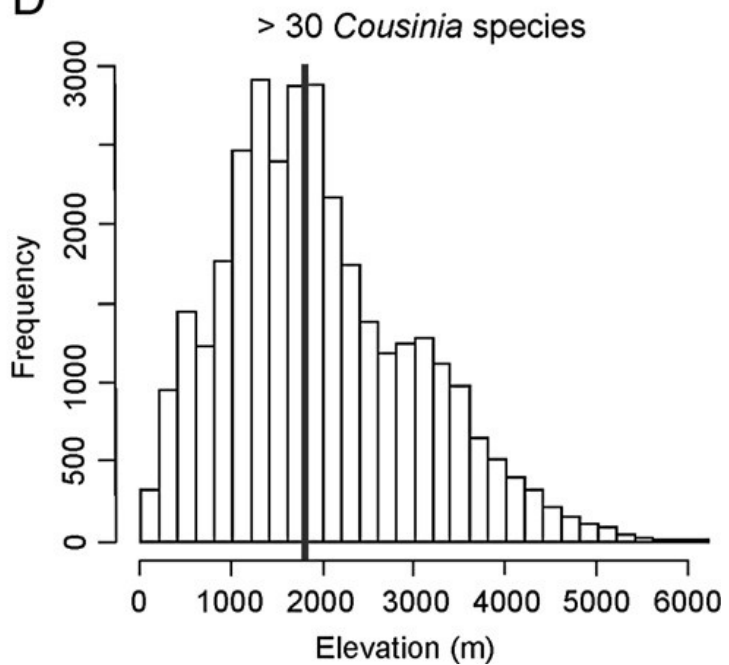

Fig. 3. Histograms showing the distribution of topography in four species diversity zones of Cousinia (Fig. 2A) proposed by Knapp (1987). The topography is taken from SRTM grids, aggregated to a 30 arcsecond grid. Frequency denotes the total number of 30 arcsecond grids corresponding to each altitudinal class. Vetical line represents the median.

Fig. 4 shows pollen percentage curves of Cousinia versus oak during the late Pleistocene-Holocene in three pollen sites located in NW Iran and SE Turkey (Lake Zeribar, NW Iran: van Zeist and Bottema, 1977; Lake Urmia, NW Iran: Bottema, 1986; Lake Van, SE Turkey: Wick et al., 2003). These diagrams clearly show that Cousinia pollen percentages were higher during the last glacial period when regional landscapes were dominated by treeless steppe vegetation, and decreased during the late glacialHolocene transition, a period characterized by gradual expansion of oak woodlands in NW Iran. The more or less continuous glacial presence of Cousinia is replaced by small peaks with very low and increasingly sporadic percentage values during the Holocene.

In Fig. 5, percentage variations of Cousinia pollen are compared with trees and upland steppe herbs for the last ca. 200 ka from Lake Urmia core BH3 (Djamali et al., 2008a). Both pollen percentages (gray-filled curves: 0-3.2\%) and concentrations (black bars: 0-142 grain/g) are illustrated. As pollen percentages of one taxon may be affected by variations in other taxa, the concentration values provide a more robust view of the temporal variations in Cousinia pollen percentages. Comparison of percentage and concentration values provides valuable information about the density of plants in the landscapes. They help to quantify the pollen deposition of a given taxon and are informative in revealing the density of that taxon in the landscape. As shown by Fig. 5 , 
in the Urmia pollen sequence, glacial intervals are characterized by the dominance of montane steppes with xerophytic upland herbs, and interglacial intervals are characterized by the expansion of trees and shrubs, especially deciduous oak and juniper woodlands. Both upland herbs and trees are considerably more frequent during the interglacial, and to a lesser extent, interstadial intervals. This indicates denser vegetation cover during the interglacial compared to glacial periods. Cousinia pollen percentages form an almost continuous curve during both the penultimate glacial (MIS 6 ) and the last glacial periods (MIS 3 and 4), but Cousinia pollen became less frequent to even absent during the last interglacial period (MIS 5e) and the Holocene (gray curve in Fig. 5C). The concentration values of Cousinia pollen showa pattern similar to the change of percentages for most of the record with some exceptions (e.g. MIS 5e). The total pollen production of upland herbs was much lower during the glacial compared to interglacial intervals, suggesting that Cousinia spp. played a very important role in the plant communities of glacial landscapes in the NW Irano-Turanian region. This is also evident by substantially higher ratio of pollen concentrations of Cousinia over upland herbs (Fig. 5F). Less frequent occurrences of Cousinia pollen during the interglacial intervals suggest that its role in the interglacial landscapes became less important. Table 2 summarizes the coefficients of variation of Cousinia pollen concentration during the climatic stages (glacial/interglacial and stadial/interstadial intervals) of the past $\sim 200 \mathrm{ka}$. (Fig. 5). Cousinia shows the lowest $\mathrm{CV}$ values during the glacial/stadial periods, compared to other herbs/trees confirming the stability and persistence of this taxon during the Quaternary cold stages.

Table 1

Details of examined late-glacial-Holocene pollen sequences of the continental Middle East.

\begin{tabular}{|c|c|c|c|c|c|}
\hline Site & Core & Longitude & Latitude & Altitude & Citation \\
\hline Lake Eski Acigöl & Eski Acigöl I & $34^{\circ} 32^{\prime} 41^{\prime \prime}$ & $38^{\circ} 33^{\prime} 01^{\prime \prime}$ & $1270 \mathrm{~m}$ & Woldring and Bottema (2001/2002) \\
\hline Lake Van & $\begin{array}{l}2 \\
13\end{array}$ & $\begin{array}{l}42^{\circ} 42^{\prime} 24^{\prime \prime} \\
42^{\circ} 32^{\prime} 07^{\prime \prime}\end{array}$ & $\begin{array}{l}38^{\circ} 28^{\prime} 20^{\prime \prime} \\
38^{\circ} 34^{\prime} 16^{\prime \prime}\end{array}$ & $\begin{array}{l}1645 \mathrm{~m} \\
1645 \mathrm{~m}\end{array}$ & van Zeist and Woldring (1978) \\
\hline Lake Van & Van-90-4 & $42^{\circ} 34^{\prime} 48^{\prime \prime}$ & $38^{\circ} 36^{\prime} 04^{\prime \prime}$ & 1645 & Wick et al. (2003) \\
\hline Lake Urmia & 20 & $45^{\circ} 26^{\prime} 52^{\prime \prime \prime}$ & $37^{\circ} 35^{\prime} 31^{\prime \prime \prime}$ & $1267 \mathrm{~m}$ & Bottema (1986) \\
\hline Lake Urmia & $\mathrm{BH} 3$ & $37^{\circ} 22^{\prime} 33^{\prime \prime}$ & $37^{\circ} 47^{\prime} 37^{\prime \prime}$ & $1265 \mathrm{~m}$ & Djamali et al. (2008a, 2008b, 2008c) \\
\hline Lake Zeribar & $\begin{array}{l}1963-J / 1970-A \\
1963-B\end{array}$ & $46^{\circ} 06^{\prime} 56^{\prime \prime}$ & $\begin{array}{l}35^{\circ} 32^{\prime} 40^{\prime \prime} \\
47^{\circ} 42^{\prime} 19^{\prime \prime}\end{array}$ & $1288 \mathrm{~m}$ & van Zeist and Bottema (1977) \\
\hline
\end{tabular}

Table 2

Coefficients of variation (CV) calculated for pollen concentration values of core $\mathrm{BH} 3$ for different depth slices corresponding to different chronological intervals.

\begin{tabular}{|c|c|c|c|c|c|c|c|c|c|}
\hline & Total land pollen & Herbs & Forbs & Trees & Artemisia & Poaceae & Centaurea & Apiaceae & Cousinia \\
\hline $\begin{array}{l}\text { Late-glacial- } \\
\text { Holocene }\end{array}$ & 0.20 & 0.26 & 0.22 & 0.09 & 0.30 & 0.29 & 1.41 & 0.94 & 0.34 \\
\hline MIS2-4 & 0.77 & 0.74 & 0.54 & 1.09 & 0.51 & 1.02 & 1.59 & 0.90 & 0.67 \\
\hline MIS5a & 0.25 & 0.29 & 0.34 & 0.24 & 0.53 & 0.30 & 0.48 & 0.83 & 0.97 \\
\hline MIS5b & 0.79 & 0.77 & 0.78 & 0.91 & 1.11 & 0.81 & 0.79 & 0.75 & 0.68 \\
\hline MIS5c & 0.69 & 0.50 & 0.40 & 1.07 & 0.44 & 0.71 & 0.49 & 1.19 & 1.04 \\
\hline MIS5d & 0.87 & 0.90 & 0.66 & 0.79 & 0.47 & 1.08 & 0.43 & 0.48 & 0.29 \\
\hline MIS5e & 0.64 & 0.63 & 0.57 & 0.68 & 0.58 & 0.78 & 0.78 & 0.84 & 1.38 \\
\hline MIS6 & 1.28 & 0.87 & 0.84 & 3.33 & 0.93 & 1.05 & 1.65 & 1.06 & 0.78 \\
\hline MIS7a & 0.25 & 0.16 & 0.06 & 0.77 & 0.11 & 0.36 & 1.08 & 0.28 & 1.49 \\
\hline Glacials & 1.11 & 0.88 & 0.78 & 2.61 & 0.90 & 1.18 & 1.50 & 0.95 & 0.72 \\
\hline Interglacials & 0.74 & 0.68 & 0.63 & 0.89 & 0.66 & 0.82 & 0.91 & 0.88 & 1.29 \\
\hline
\end{tabular}




\section{Discussion}

\subsection{Persistence of Cousinia in glacial landscapes of the Irano-Turanian region}

The Cousinia-type pollen recorded in NW Iranian and E Anatolian regions (see pictures in van Zeist and Bottema, 1977) most probably was produced exclusively by species of Cousinia s.str. as defined above (see also Shtepa, 1976; Saber et al., 2009). Cousinia is both insect- and self-pollinated (Funk et al., 2009; López-Vinyallonga et al., 2009) and is therefore under-represented in the modern pollen rain. Although Cousinia is one of the dominant constituents of the Irano-Turanian flora today, its pollen has either not been found (e.g. Wright et al., 1967; van Zeist et al., 1970; Bottema and Barkoudah, 1979; Djamali et al., 2008c) or only been found at extremely low values (b1\%) in modern pollen-vegetation studies in Iran and surrounding areas (van Zeist and Bottema, 1977; Moore and Stevenson, 1982). This suggests that this genus formed a major component of the Irano-Turanian glacial steppes in NW Iran during the glacial periods, where Cousinia pollen percentages were close to $3 \%$. Further, the quasicontinuous percentage curve, the high concentration values and low $\mathrm{CV}$ index of Cousinia-type pollen during the last glacial and penultimate glacial periods (Fig. 5 , Table 2) provide evidence for the persistence of vegetation with abundant Cousinia on upland slopes around Lake Urmia. Note the high values of ratio of Cousinia over upland herbs during glacial periods (Fig. $5 \mathrm{~F}$ ) that indicates the higher abundance of Cousinia compared to other steppe herbs. Identifying other elements of these glacial plant communities is problematic due to the under-representation of many IranoTuranian genera. However, the higher glacial-age pollen values of Plumbaginaceae and Fabaceae (see pollen data of cores $\mathrm{BH} 2$ and $\mathrm{BH} 3$ in European Pollen Database: http://www.europeanpollendatabase.net/) may have been mainly produced by Acantholimon, Onobrychis and Astragalus, three important Irano-Turanian steppe taxa.

A detailed review of the altitudinal range of extant species of Cousinia is useful in understanding their response to Quaternary glaciations. Currently, Cousinia species grow across a wide range of altitudes. For example, in the Irano-Turanian part of Golestan National Park (NE Iran), the 14 species reported in Akhani (1998) are distributed from 900 to $2200 \mathrm{~m}$. In the Anatolian plateau and adjacent Mesopotamian lowlands, Cousinia ranges between 320 and $3450 \mathrm{~m}$ (Davis et al., 1965-1988). In the flora of the alpine zone of Iran (3000-4000 m), Cousinia constitutes one of the largest genera with more than 20 species, of which 18 are endemic to Iranian high mountain systems (Noroozi et al., 2008). The genus is also represented by many species in the subalpine thorn-cushion vegetation belts of Iran, Iraq and Turkey (Davis et al., 19651988; Guest and Al-Rawi,1966; Klein, 2001). This large altitudinal variation shows that Cousinia can grow in a broad range of elevations. However, individual Cousinia species commonly have narrow altitudinal ranges. For instance, in Golestan National Park, most of the Cousinia species are limited to a narrow $(320 \mathrm{~m})$ elevation range (Akhani, 1998). 


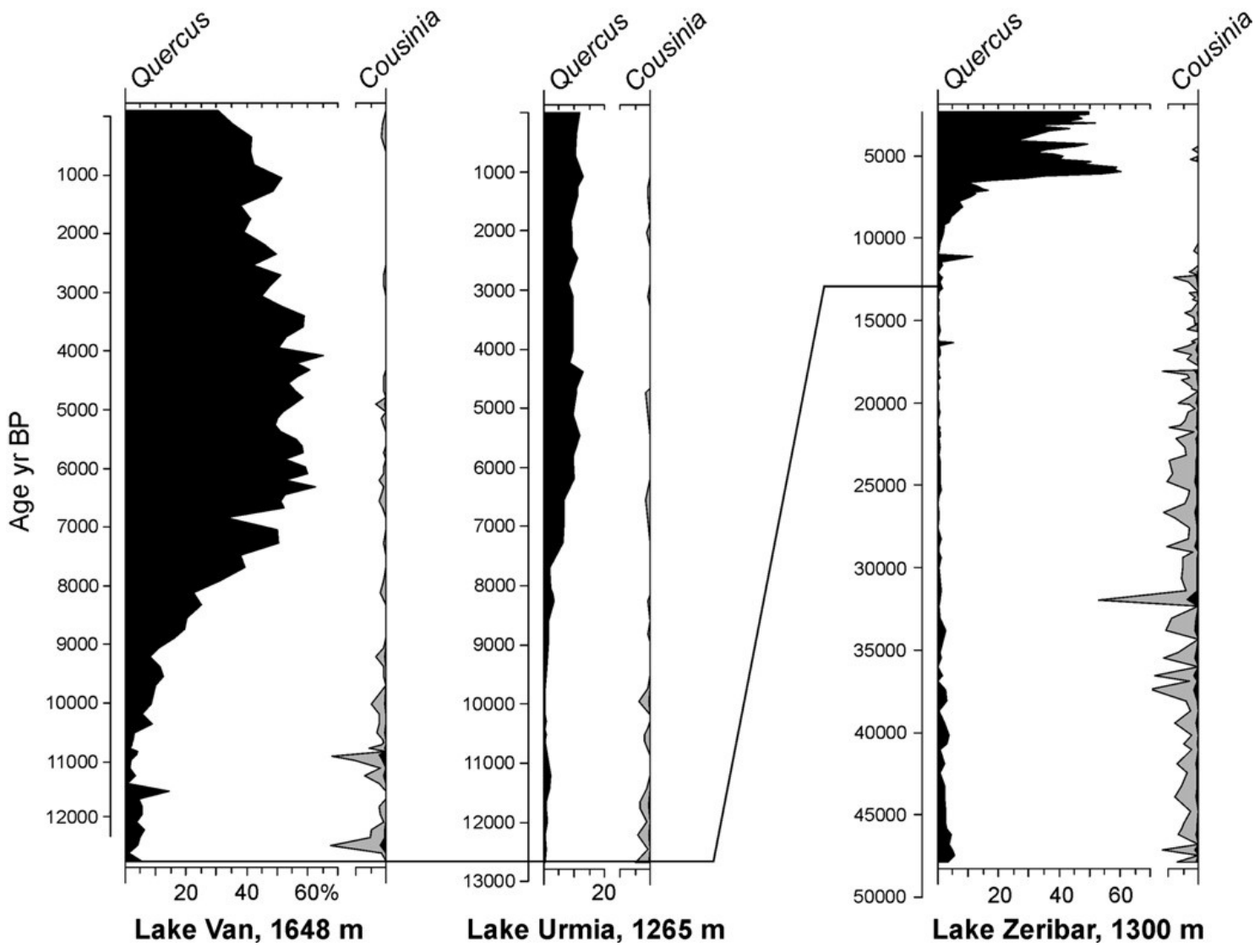

Fig. 4. Pollen percentage variations of Cousinia during the late-glacial-Holocene in lakes Van and Urmia and also the Last Glacial to Holocene in Lake Zeribar. Pollen data are taken from van Zeist et al. (1970), Bottema (1986), and van Zeist and Bottema (1977) available as pollen counts in the website of the European Pollen Database (http://www.europeanpollendatabase.net/).

In mountain systems, climatic changes lead to vertical rather than horizontal shifts of plant species and communities. These altitudinal range shifts allow species to track their optimal habitats by short-distance migration. However, the location and complexity of the high mountain systems are of critical importance to understand how species ranges shifted, as well as to understand the evolutionary history of mountain species (Alvarez et al., 2009; Schmitt, 2009). For example, in the main range of the Alps, such vertical migrations were difficult if not impossible due to the lowered snowline and the large extension of glaciers covering large parts of mountain slopes (e.g. Kelly et al., 2004). The high number of local endemics in Central European high mountain systems indicates their isolation and survival in non-glaciated areas located in (i) low altitude habitats in peripheral regions and (ii) high altitude "nunataks" (Schönswetter et al., 2005; Hu et al., 2008; Thiel-Egenter et al., 2008; Schmitt, 2009). In contrast, in the mountainous regions in southern Europe, e.g. the Sierra Nevada in the Iberian Peninsula, the extension of glaciers and snowline descent were less pronounced, leaving vertical space for the survival and vertical migration of many species and having in significant impact on the genetic structure of plant and animal populations (e.g. Gutiérrez Larena et al., 2002; Schmitt, 2009). Major glacial refugia in Europe were located in topographically heterogeneous areas in southern and southeastern Europe (Caucasus region) (Huntley and Birks, 1983; Taberlet and Cheddadi, 2002; Tzedakis et al., 2002; Leroy and Arpe, 2007; Médail and Diadema, 2009; Arpe et al., 2011). By contrast, in the northern Andes of Colombia, another example of low latitude mountain systems $\left(\sim 5^{\circ} \mathrm{N}\right)$, the highest vegetation belt kept nearly the same altitudinal extension as today during the LGM, i.e. between 2000 and 3000m (Hooghiemstra et al., 2006). 


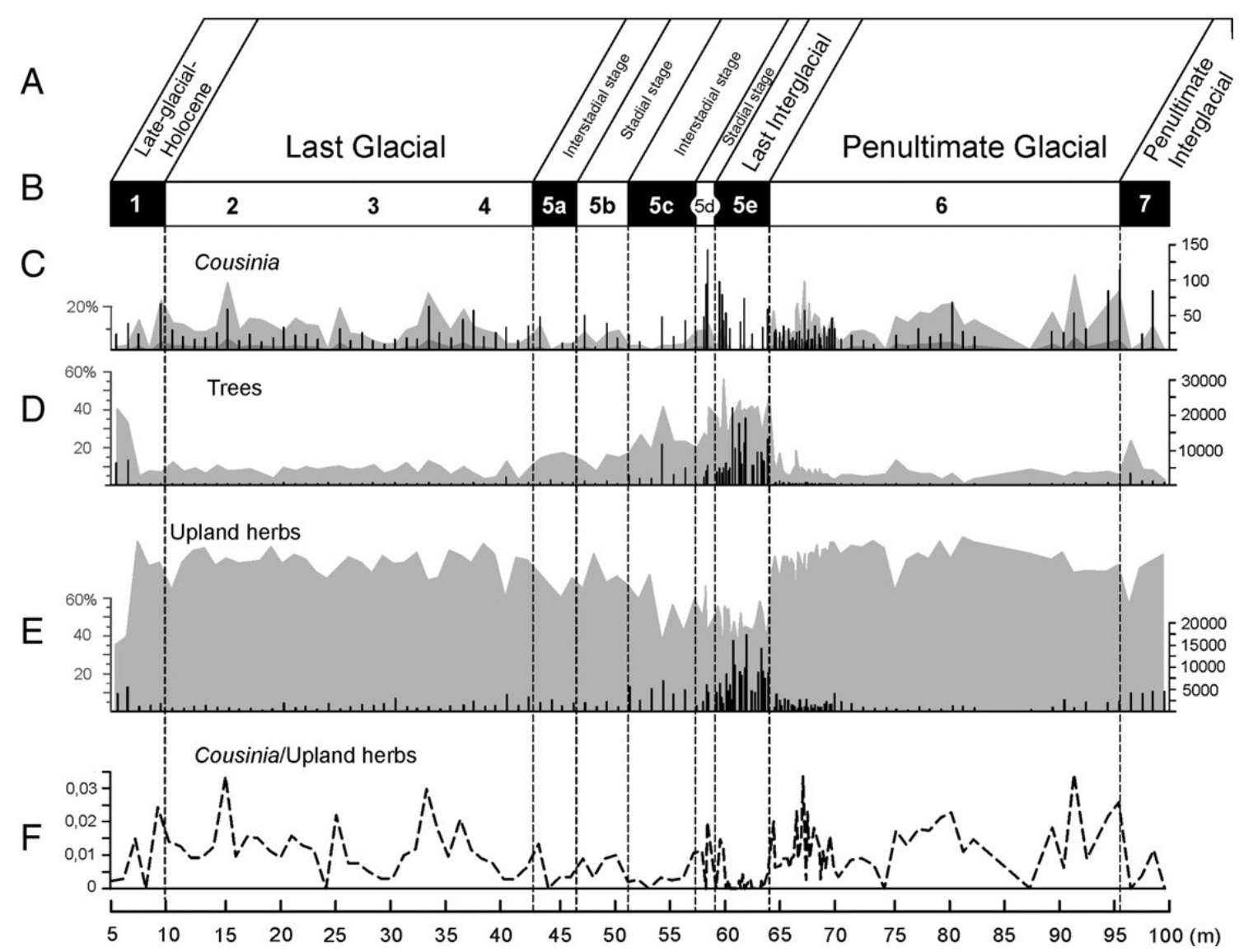

Fig. 5. Pollen percentage and concentration variations for a selection of taxa from a long pollen record of Lake Urmia (Djamali et al., 2008a). A. chronostratigraphy, B. Marine Isotope Stages, C. Cousinia pollen percentages (gray-colored curves) and concentrations (bars). Darker gray show the real percentages and lighter gray show three-fold exaggeration. D. and E. show the pollen percentages (gray-colored curve) and concentrations (bars) of trees and upland herbs. F. Ratio of Cousinia/Upland herb concentrations. Note that Cousinia displays a more continuous curve during glacial periods and sporadic occurrences during the interglacial periods $(\mathrm{C})$ and its role in the landscape is much less important during the interglacial intervals $(F)$.

In the low latitude mountain ranges of SW Asia, the snowline was considerably higher than in Europe and glacier extension was less developed. The lower extent of glacier advances may have resulted from lower precipitation compared to northern latitudes of Europe in glacial times. Likewise, the vegetation belts of the Irano-Turanian region in the Alborz Mountains lie about $1000 \mathrm{~m}$ higher than their equivalent belts in the European Alps (Klein, 2001). In SE Iran, the snowline dropped $\sim 1500-1600 \mathrm{~m}$ to the altitudes of $\sim 2950-3050 \mathrm{~m}$ a.s.l. during the last glacial and penultimate glacial periods, respectively (Kuhle, 2008). The Last Glacial snowline in the Hindu Kush Mountains of Afghanistan, which form a main diversity center for Cousinia (Knapp,1987), dropped about $1000 \mathrm{~m}$ and was located between $\sim 4000$ and $4600 \mathrm{~m}$ a.s.l. (Porter, 2004). Therefore, we can assume that during thelate Pleistocene glaciations the snowline descent in SW Asia left a wide altitudinal range uncovered by ice which could have been colonized by downward-migrating Irano-Turanian high altitude species including Cousinia. TheQuaternary climatic oscillations therefore, caused a downward shift rather than elimination of themontane and sub-alpine vegetation belts ("Oro-IranoTuranian" and "Alti-Irano-Turanian" senso Klein, 2001). In NW Iran, the snowline descent has been estimated to $\sim 1200 \mathrm{~m}$ (Wright, 1961). Lake Urmia, located at an altitude of $1250 \mathrm{~m}$ a.s.l., would have been surrounded by plants which now grow above $2450 \mathrm{~m}$ a.s.l. Today, this vegetation in the Alborz Mountains includes the Lower AltiIrano-Turanian zone (2500-3200 m a.s.I.), dominated by Juniperus excelsa open woodlands, and the Upper Alti-Irano-Turanian zone (>3200m a.s.I.; Klein, 2001). Both 
of these zones are dominated by Irano-Turanian thorny cushion plants such as Astragalus, Onobrychis, Acantholimon, and Cousinia.

Taking these factors into consideration, we agree with El-Moslimany's (1987) interpretation of pollen diagrams of NWIran, in which it was suggested that the upland vegetation of this region during the last two glacial periods had physiognomic similarities to the vegetation of these high-altitude zones. The reduced impact of glaciations in the Irano-Turanian mountains left vast ice-free areas which were inhabited by vegetation currently found at higher elevations, in which Cousinia species constituted an important element.

\subsection{Cousinia species diversity and topographical heterogeneity of SW Asia}

In an analysis of the modern geographical distribution of Cousinia species in SW Asia, Knapp (1987) made the following observations: (i) The distribution of Cousinia is almost perfectly limited to the Irano-Turanian phytogeographical region, a pattern shared with other typical Irano-Turanian genera (e.g., Astragalus, Acantholimon, Acanthophyllum, Eremostachys, Eremurus; Fig. 1). (ii) The great majority of Cousinia species are found in themountain regions of Iran, Afghanistan, and Central Asia. The number of Cousinia species rapidly decreases towards lower altitudes, and very few species are found in temperate desert areas of Iran and Central Asia (Figs. 1 and 2). (iii) Most of the recorded Cousinia species have very restricted distribution ranges and constitute local endemics. The high rate of endemism of Cousinia can be exemplified by the high number of narrow endemic species ( 110 spp.) of sect. Cynaroideae in SE Turkey, N Iraq, and NW Iran (Mehregan, 2008).

Our topographical analysis of Cousinia species richness clearly indicates that diversity is highest in areas of higher elevation, but also in those with more variability in elevation (Figs. 2B and $\underline{3}$ ). Thus, topography appears to be linked to the spatial distribution of Cousinia species diversity. This fact is confirmed by the modern distribution patterns of Cousinia spp., which commonly show relatively restricted ranges (Knapp, 1987; see also the maps in Davis et al., 1965-1988; Attar and Ghahreman, 2006; Mehregan, 2008). A high frequency of small-range species and local endemics of Cousinia is the result of topographically induced habitat heterogeneity, which permits the adaptation of species to different habitats. This link between topographical heterogeneity and high plant biodiversity, high number of smallrange and rare species, and high rate of speciation has previously been demonstrated in many studies (e.g. Qi and Yang, 1999; Coblenz and Riitters, 2004; Ohlemüler et al., 2008). Topography creates spatial and ecogeographic barriers between plant populations and increases the probability of speciation via allopatry (Stebbins, 1950; Rieseberg and Willis, 2007; Hendry, 2009).

Climate change and tectonism are the most important factors that can affect distribution patterns, and ongoing debates center on their relative importance for speciation and endemism (e.g. Kohn and Fremd, 2008; Badgley, 2010; Hoorn et al., 2010). The comparison of estimated ages of speciation/divergence and tectonic phases and climatic oscillations is therefore important to understand the causes of speciation processes. López-Vinyallonga et al. (2009) recently provided a comprehensive study of the phylogeny of the Arctium-Cousinia complex. On the basis of the phylogenetic signal of two DNA regions and molecular dating approaches, they demonstrated that the Arctium-Cousinia complex and more particularly Cousinia s.str. has undergone a "massive radiation" in recent geological time. The major diversification of this clade, containing about 200 species, most probably occurred after $\sim 7$ million years ago (Ma), so that much speciation took place in the late Tertiary and probably the Quaternary. As this time span is contemporaneous with an intensified 
interval of tectonic activities in SW Asia, we review here the tectonic evolution of the Turkish-Iranian Plateau to understand how this contributed to the present diversity of the Irano-Turanian flora.

\subsection{Role of tectonic evolution of SW Asia for plant diversity}

The topography of SW Asia reflects post-Miocene earth-surface processes and tectonic deformations related to the Arabia-Eurasia collisional convergence (e.g. Falcon, 1974; Bozkurt, 2001; Koçyigit et al., 2001; Guest et al., 2007). This plate convergence, which began in the Late Cretaceous ( 90 Ma; Şengör and Yılmaz, 1981; Dewey et al., 1986; Dewey et al., 1989), resulted in the progressive closure of the Neotethyan oceanic basins, the amalgamation of the surrounding continental fragments, and the continental collision (e.g. Berberian and King, 1981; Bozkurt, 2001). This led to the subsequent emplacement of the majority of the mountain ranges in the Turkish-Iranian Plateau, including the Anti-Taurus, Zagros, Alborz, and Kopeh Dagh ranges. Spatial variation in lithospheric characteristics of the Plateau involved in the continental deformation created a large variety of physiographic domains roughly similar to the present-day configuration. The Arabia-Eurasia collision started at $\sim 35$ $\mathrm{Ma}$, with the final closure of the Neo-Tethys at $20 \mathrm{Ma}$ (e.g., Mouthereau and Lacombe, accepted for publication and references therein). The main stages of crustal thickening $(\sim 25 \mathrm{Ma})$ and the uplift of the Iranian Plateau ( 15-12 Ma), however, took place between the Late Oligocene and Late Miocene ( 25-12 Ma; Dewey and Şengör, 1979; Woodruff and Savin, 1989; McQuarrie et al., 2003; Homke et al., 2004; Fakhari et al., 2007; Verdel et al., 2007). Afterward, a complex sequence of deformation took place leading to further uplift (e.g., Axen et al., 2001; Guest et al., 2007) and tectonic rearrangement (e.g., Ritz et al., 2006; Shabanian et al., 2009 and references therein) of the mountain ranges.

The timing of the formation of all mountain ranges was, howeverot synchronous, either within the Plateau or between the Plateau and Central Asia. For instance, the region presently occupied by the central axis of the Alborz Mountains already separated the Caspian basin from central Iran by the Eocene (Stöcklin, 1974; Berberian, 1983; Brunet et al., 2003), whereas the formation of the western Alborz mountains started only in the late middle Miocene ( $12 \mathrm{Ma}$; e.g., Guest et al., 2007). In the fold-and-thrust belt of Zagros (Fig. 2B), the main regional shortening has been suggested to have taken place since the late Miocene and during the Pliocene (Falcon, 1974; Haynes and McQuillan, 1974; Stoneley, 1981; Hessami et al., 2001; Sherkati and Letouzey, 2004).

This description suggests that despite the lack of regional synchroneity, the geological age estimates for the main orogenic belts of the Turkish-Iranian Plateau predates the age estimated for the rapid radiation of Cousinia at $\sim 7$ Ma (López-Vinyallonga et al., 2009). A similar relationship has been observed between the estimated age of a huge monophyletic group of Lupinus in the Western Hemisphere $(\sim 1.18-1.76 \mathrm{Ma})$ and the major uplift of the Andes that started $\sim 3-5 \mathrm{Ma}$ and continues to the present (Hughes and Eastwood, 2006). The floristic evaluation of long palaeoecological records in the basin of Bogotá (2550 m; Eastern Cordillera, Colombia) has shown that the late Cenozoic Andean uplift has played a major role in the evolution and distribution of the flora of the northern Andes (Hooghiemstra et al., 2006). In case of Cousinia, speciation would have taken place in a region in which the topography was already varied. The effect of topographical features on diversity is most evident in the Zagros Mountains where different stages of topographical evolution can be observed (e.g., Hessami et al., 2001). For instance, the southwestern frontal part of the Zagros Mountains (FZ; Fig. 2B), which is clearly younger (b12 Ma) than its axial part (b20 Ma), harbors the lowest species diversity whereas the adjacent older mountain systems, with almost the same topographical conditions, show highest species diversity. This raises the possibility that 
the continuing rapid uplift of the southern Zagros will favor the propagation of the IranoTuranian flora into the Saharo-Sindian region.

\subsection{Climatic oscillations and evolution of the Irano-Turanian flora; inferences from the palaeoecology and phylogeny of Cousinia as a system model}

The ecological and evolutionary responses of flora and fauna to Quaternary climatic instability have long been a matter of debate. Several ecological responses of species to Milankovitch oscillations can be recognized: persistence in situ, moderate shifts in habitat, migration, and extinction (Jackson and Overpeck, 2000; Bennett, 2004). Some authors have suggested that 'extinction' and, to a lesser extent, 'persistence' probably were the dominant modes of response to these climatic oscillations, especially during the glacial periods (Bennett, 2004; Willis and Niklas, 2004), but others have demonstrated that the migration of plant populations was the most common biotic response (e.g. Huntley and Webb, 1989; Jackson et al., 1997; Brewer et al., 2002). From an evolutionary point of view, it has also been suggested that the multiple glacial-interglacial cycles did affect the genetic diversity of plant populations (e.g. Petit et al., 2003) but did not profoundly influence speciation rates (e.g. Bennett, 1990; Dynesius and Jansson, 2000; Bennett, 2004; Willis and Niklas, 2004; Barnosky, 2005; Lemmon et al., 2007). This has been attributed to the relatively short duration of isolation during glacial periods and gene flow in the short interglacial intervals which inhibited the formation of reproductive barriers (Dynesius and Jansson, 2000; Willis and Niklas, 2004). However, the steady accumulation of dated molecular phylogenies has shown that the Quaternary, instead, was a period of rapid speciation in ecologically and climatically different environments suggesting a link between climate and diversification (Richardson et al., 2001; von Hagen and Kadereit, 2001; Kadereit and Comes, 2004; Hughes and Eastwood, 2006; Zhang et al., 2007; Brochmann and Brysting, 2008; Bittkau and Comes, 2009; Janssens et al., 2009; Valente et al., 2010).

In case of Cousinia, it seems that the late Tertiary orogenic movements in SW Asia, rather than Quaternary climatic oscillations, account for most of the speciation in the genus. The late Tertiary (b20 Ma) corresponds to the onset of severe continental conditions (high range of daily and seasonal temperature variations) in SW Asia (Strömberg et al., 2007) which developed after the retreat of the Oligo-Miocene seas from vast areas of SW Asia (Bosboom et al., 2011). Increased continentality has been proposed by Knapp (1987) as the main bioclimatic factor controlling the geographic range of Cousinia. Despite the lack of a synthesis treating the palaeoclimatic history of SW Asia during the Tertiary time, the presence of very thick Mio-Pliocene clastic red beds over large areas of Iran provides evidence of such prevailing continental conditions (Berberian and King, 1981; Amini, 1997). A recent sedimentological and geochemical study of this formation in north-central Iran suggested some variation in the intensity of aridity during the mid- to late Miocene period that seems to be a result mainly of the uplift of the Alborz Mts in northern Iran and to lesser extent of perturbations in atmospheric circulation patterns (Ballato et al., 2010). However, the general climate of the region remained semi-arid in spite of this variation. At a global scale, temperatures during the early to mid-Miocene $(\sim 24-13 \mathrm{Ma})$ were significantly higher than in the Quaternary period (Fig. 6) and started to decrease after the 'MidMiocene Climatic Optimum', the onset of the East Antarctic ice-sheet formation (Zachos et al., 2001). Hence, during the early to mid-Miocene, global climate was relatively stable with no large-scale cooling/warming events (Fig. 6). During the Late Miocene-Pliocene, although the climate showed some degree of oscillation affecting the terrestrial vegetation, the contrasts between cold and warm stages were not as severe as in the Quaternary (e.g. Leroy and Dupont, 1994; see also Fig. 2 in Zachos et al., 2001). In summary, the climatic conditions during the Miocene-Pliocene time 
interval would not have caused significant range shifts favoring allopatric speciation in Cousinia.

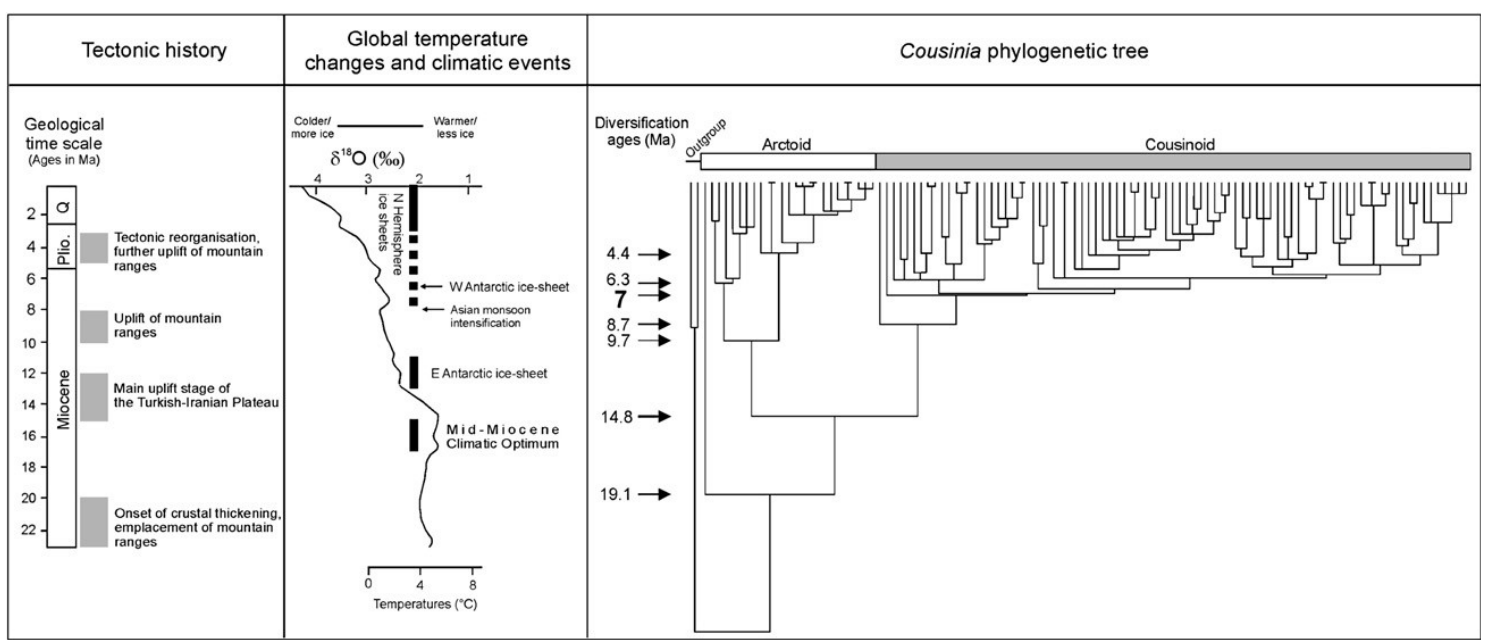

Fig. 6. Synthetic picture to compare the tectonic history, global climate, and the diversification ages of the ArctiumCousinia complex. Climatic information are derived from Zachos et al. (2001) (Fig. 2). The solid line corresponds to the smoothed raw oxygen isotope data obtained from a compilation of several DSDP and ODP sites mainly measured on two benthic taxa (Cibicidoides and Nuttallides). Phylogenetic tree is re-drawn from Fig. 5 in López-Vinyallonga et al. (2009). Note that the most important diversification event in Cousinia occurred after the uplift of the Turkish-Iranian Plateau and the formation of the mountain ranges.

The Quaternary glacial-interglacial cycles, which started $\sim 2.6 \mathrm{Ma}$ at the beginning of the Quaternary (Gibbard et al., 2009), became intensified during the "Mid-Pleistocene Revolution" at $\sim 1$ to $\sim 0.6 \mathrm{Ma}$ (Maslin, 2009), and their effects on terrestrial vegetation became sig-nificantly stronger during this climatic transition (e.g. de Beaulieu et al., 2005). This time is, by far, younger than the estimated age for major speciation events in Cousinia, which predate the Quaternary glaciations (López-Vinyallonga et al., 2009). Therefore, we suggest that the Quaternary climatic oscillations would not have had an important impact on speciation in Cousinia and other large Irano-Turanian plant taxa. The few speciation events of Cousinia during the glacial-interglacial cycles are likely to have mainly occurred in high-altitude "interglacial refugia" (Bennett and Provan, 2008). These are the deglaciated high-elevation mountain areas re-colonized by upwardmigrating xeric and cold-adapted species during the interglacial periods. Presence of such high-altitude "interglacial refugia" in the NW Irano-Turanian region has already been demonstrated based on the presence of sub-fossil remains of boreal-arctic relict species (Djamali, 2008; Kürschner and Djamali, 2008). Restriction to these refugia can potentially cause genetic differentiation during the interglacial intervals. This hypothesis of speciation in "interglacial refugia" has important implications, as it suggests that the evolutionary response of plant taxa to climatic oscillations may vary considerably between mountain systems of high versus low latitudes. Hence, in contrast to the Alps where speciation has been suggested to have taken place in geographically isolated low-altitude "glacial refugia" (e.g. Kadereit et al., 2004), in the southern IranoTuranianmountain systems diversification would have been concentrated in geographically isolated highaltitude "interglacial refugia".

\section{Conclusion}

Our current knowledge of the diversification and palaeoecology of the Irano-Turanian flora is very scanty and the hypotheses proposed in this study remain to be tested in future studies. However, longterm variation in Cousinia pollen records from the IranoTuranian region help to understand the general response of the flora of similar ecology 
and geographical distribution (e.g. Astragalus, Acantholimon, Acanthophyllum) of this region to Quaternary glaciations. The available palaeoecological records show that Cousinia was present and more abundant during glacial periods, suggesting that the Irano-Turanian flora not only survived the Quaternary glaciations, but that Cousinia as well as probably several other important Irano-Turanian taxa were more widespread in glacial-age landscapes than they are today. According to a dated molecular phylogeny of Cousinia (López-Vinyallonga et al., 2009), the major radiation of this genus dates to long before the beginning of the Quaternary climatic instability. Hence, it is likely that the continued presence of the heterogeneous topography of SW Asia since the late Tertiary, coupled with a relatively stable continental climate, caused long-term uninterrupted isolation, leading to high rates of allopatric speciation (Fig. 6), and adaptation to spatially restricted ecological niches. The climatic instability of the Quaternary had only a minor impact on isolation, and populations of endemic species persisted in their native regions. Further diversification (e.g. allopatric or sympatric speciation) during the Quaternary glacial-interglacial cycles probably took place during interglacials in high-altitude "interglacial refugia".

\section{Uncited references}

Akhani, 2007

Al-Nafie, 2008

Coblentz, 2005

Jackson et al., 2005

Jonsson and Dynesius, 2002

Léonard, 1981-1989

Léonard, 1993

Magyari et al., 2008

\section{Acknowledgments}

This study was supported by funds from the University of Wyoming and the National Science Foundation. Discussions with Professor Hossein Akhani (University of Tehran), Drs. Bruno Fady (INRA Avignon-IMBE) and Jérémy Miglore (IMBE) were valuable in the improvement of paper. We are very grateful to Prof. Suzanne Leroy and two anonymous reviewers for their thoughtful and constructive comments on this manuscript.

\section{References}

Akhani, H., 1998. Plant biodiversity of Golestan National Park, Iran. Stapfia 53, 1-411.

Akhani, H., 2007. Diversity, biogeography, and photosynthetic pathways of Argusia and Heliotropium (Boraginaceae) in South-West Asia with an analysis of phytogeographical units. Botanical Journal of the Linnean Society 155, 401-425.

Al-Nafie, A.H., 2008. Phytogeography of Saudi Arabia. Saudi Journal of Biological Sciences 15, 159-176.

Alvarez, N., Thiel-Egenter, C., Tribsch, A., 2009. History or ecology? Substrate type as a major driver of spatial genetic structure in Alpine plants. Ecology Letters 12, 632-640.

Amini, A., 1997. Provenance and depositional environment of Upper Red Formation, central zone, Iran. Unpublished PhD thesis, Manchester University, Manchester.

Arpe, K., Leroy, S.A.G., mikolajewicz, U., 2011. A comparison of climate simulations for the last glacial maximum with three different versions of the ECHAM model and implications for summer-green tree refugia. Climate Past 7, 91-114.

Attar, F., Ghahreman, A., 2006. A synopsis of sect. Cynaroides (Cousinia, Compositae), distribution, patterns and diversity centers. Rostaniha 7 (Suppl. 2), 315-342.

Badgley, C., 2010. Tectonics, topography, and mammalian diversity. Ecography 33, 220-231.

Ballato, P., Mulch, A., Landgraf, A., strecker, M.R., Dalconi, M.C., Anke, F., Tabatabaei, S.H., 2010. Middle to late Miocene Middle Eastern climate from stable oxygen and carbon isotope data, southern Alborz mountains, N Iran. Earth and Planetary Science Letters 300, 125-138. 
Barnosky, A.D., 2005. Effects of Quaternary climatic change on speciation in mammals. Journal of Mammalogy Evolution 12, 247-264.

Bennett, K.D., 1990. Milankovitch cycles and their effects on species in ecological and evolutionary time. Paleobiology 16, 11-21.

Bennett, K.D., 2004. Continuing the debate on the role of Quaternary environmental change for macroevolution. Philosophical Transactions of the Royal Society of London. Series B 359, 295303.

Bennett, K.D., Provan, J., 2008. What do we mean by 'refugia'? Quaternary Science Reviews 27, 24492455.

Berberian, M., 1983. The southern Caspian: a compressional depression floored by a trapped, modified oceanic crust. Canadian Journal of Earth Sciences 20, 163-183.

Berberian, M., King, G.C.P., 1981. Towards a paleogeography and tectonic evolution of Iran. Canadian Journal of Earth Sciences 18, 210-265.

Bittkau, C., Comes, H.P., 2009. Molecular inference of a Late Pleistocene diversificationshift in Nigella s. lat. (Ranunculaceae) resulting from increased speciation in the Aegean archipelago. Journal of Biogeography 36, 1346-1360.

Bosboom, R.E., Dupont-Nivet, G., Houben, A.J.P., Brinkhuis, H., Villa, G., Mandic, O., Stoica,M., Zachariasse, W.J., Guo, Z., Li, C., Krigsman,W., 2011. Late Eocene sea retreat from the Tarim (west China) and concomitant Asian palaeoenvironmental change. Palaeogeography Palaeoclimatology Palaeoecology 299, 385-398.

Bottema, S., 1986. A late Quaternary pollen diagram from Lake Urmia (northwestern Iran). Review of Palaeobotany and Palynology 47, 241-261.

Bottema, S., Barkoudah, Y., 1979. Modern pollen precipitation in Syria and Lebanon and its relation to vegetation. Pollen et Spores 21, 427-480.

Bottema, S., Woldring, H., 1984. Late Quaternary vegetation and climate of southwestern Turkey, Part II. Palaeohistoria 26, 123-149.

Bozkurt, E., 2001. Neotectonics of Turkey-a synthesis. Geodinamica Acta 14, 3-30.

Brochmann, C., Brysting, A.K., 2008. The Arctic-an evolutionary freezer? Plant Ecology and Diversity 1, 181-195.

Brunet, M.F., Korotaev, M.V., Ershov, A.V., Nikishin, A.M., 2003. The South Caspian Basin: a review of its evolution from subsidence modeling. Sedimentary Geology 156, 119-148.

Coblentz, D., 2005. The tectonic evolution of the Madrean Archipelago and its impact on the geoecology of the Sky Islands. USDA Forest Service Proceedings RMRS-P-36, pp. 62-68.

Coblenz, D.D., Riitters, K.H., 2004. Topographic controls on the large-scale biodiversity of the southwestern USA. Journal of Biogeography 31, 1125-1138.

Couvreur, T.L.P., Franzke, A., Al-Shehbaz, I.A., Bakker, F.T., Koch, M.A., Mummenhoff, K., 2010. Molecular phylogenetics, temporal diversification, and principles of evolution in the mustard family (Brassicaceae). Molecular Biology Ecology 27, 55-71.

Davis, P.H., Cullen, J., Coode, M.J.E., 1965-1988. Flora of Turkey and the East Aegean Islands, I. Edinburgh University Press, Edingburgh.

de Beaulieu, J.-L., Andrieu-Ponel, V., Cheddadi, R., Guiter, F., Ravazzi, C., Reille, M., Rossi, S., 2005. Apport des longues séquences lacustres à la connaissance des variations des climats et des paysages pléistocènes. Comptes Rendus Palevol 5, 65-72.

Dewey, J.F., Şengör, A.M.C., 1979. Aegean and surrounding regions: complex multiplate and continuum tectonic in a convergent zone. Geological Society of America Bulletin 90, 84-92.

Dewey, J.F., Hempton, M.R., Kidd, W.S.F., Saroğlu, F., Şengör, A.M.C., 1986. Shortening of continental lithosphere: the neotectonics of eastern Anatolia-a young collision zone. In: Coward, M.O., Ries, A.C. (Eds.), Collisional Tectonics. Geol. Soc. Spec. Publ., No. 19. Geological Society, London, pp. 3-36.

Dewey, J.F., Helman, M.L., Turco, E., Hutton, D.H.W., Knott, S.D., 1989. Kinematics of the western Mediterranean. In: Coward, M.P., Dietrich, D., Park, R.G. (Eds.), Alpine Tectonics. Geol. Soc. Spec. Publ., No. 45. Geological Society, London, pp. 265-283.

Djamali, M., 2008. Changements paléoenvironnementaux en Iran au cours des deux derniers cycles climatiques (végétation-climat-anthropisation). Unpublished $\mathrm{PhD}$ thesis, University of Paul Cézanne, Marseille.

Djamali, M., de Beaulieu, J.-L., Shah-Hosseini, M., Andrieu-Ponel, V., Amini, A., Akhani, H., Leroy, S.A.G., Stevens, L., Alizadeh, H., Ponel, P., Brewer, S., 2008a. An Upper Pleistocene long pollen record from the Near East, the 100 m-long sequence of Lake Urmia, NW Iran. Quaternary Research 69, 413-420.

Djamali, M., Kürschner, H., Akhani, H., de Beaulieu, J.-L., Amini, A., Andrieu-Ponel, V., Ponel, P., Stevens, L., 2008b. Palaeoecological significance of the spores of the liverwort Riella (Riellaceae) in a late Pleistocene long pollen record from the hypersaline Lake Urmia, NW Iran. Review of Palaeobotany and Palynology 152, 66-73.

Djamali, M., de Beaulieu, J.-L., Campagne, P., Ajani, Y., Andrieu-Ponel, V., Ponel, P., Cheikh Albassathneh, M., Leroy, S., 2008c. Relations pluie pollinique-végétation sur un transect forêtsteppe dans le parc national du Golestan, nord-est de I'Iran. Ecologia Mediterranea 34, 35-52. 
Dynesius,M., Jansson, R., 2000. Evolutionary consequences of changes in species' geographical distributions driven by Milankovitch climate oscillations. PNAS 97, 9115-9120.

Eig, A., 1931. Les éléments et les groupes phytogéographiques auxiliaires dans la flore palestinienne: Texte. Beihefte zum Repertorium Specierum Novarum Regni Vegetabilis, Band LXIII. Verlag des Repertoriums, Berlin. (201 pp.).

El-Moslimany, A.P., 1987. The late Pleistocene climates of the Lake Zeribar region (Kurdistan, western Iran) deduced from the ecology and pollen production of non-arboreal vegetation. Vegetatio 72 , 131-139.

Fakhari, M.D., Axen, G.J., Horton, B.K., Hassanzadeh, J., Amini, A., 2007. Revised age of proximal deposits in the Zagros foreland basin and implications for Cenozoic evolution of the High Zagros. Tectonophysics 451, 170-185.

Falcon, N.L., 1974. Southern Iran: Zagros Mountains, in Mesozoic-Cenozoic Orogenic Belts, Data for Orogenic Studies. Geological Society Special Publication 4, 199-211.

Funk, V.A., Susanna, A., Stuessy, T.F., Bayer, R.J., 2009. Systematics, Evolution, and Biogeography of Compositae. International Association for Plant Taxonomy, Vienna. (965 pp.).

Gibbard, P.L., Head, M.J., Walker, M.J.C., 2009. Formal ratification of the Quaternary System/Period and the Pleistocene Series/Epoch with a base at 2.58 Ma. Journal of Quaternary Science 25, 96-102.

Grimm, E.C., 2004/2005. TILIA and TGView Software. Ver. 2.0.2. Illinois State University, Illinois.

Guest, E., Al-Rawi, A., 1966. Flora of Iraq, I. Ministry of Agriculture, Baghdad. (213 pp.).

Guest, B., Guest, A., Axen, G., 2007. Late Tertiary tectonic evolution of northern Iran: a case for simple crustal folding. Global and Planetary Change 58, 435-453.

Gutiérrez Larena, B., Fuertes Aguilar, J., Nieto Feliner, G., 2002. Glacial-induced altitudinal migrations in Armeria (Plumbaginaceae) inferred from patterns of chloroplast DNA haplotype sharing. Molecular Ecology 11, 1965-1974.

Haynes, S.J., McQuillan, H., 1974. Evolution of the Zagros Suture Zone, southern Iran.Geological Society of America Bulletin 85, 739-744.

Hendry, A.P., 2009. Speciation. Nature 458, 162-164.

Hessami, K., Koyi, H.A., Talbot, C.J., Tabasi, H., Shabanian, E., 2001. Progressive unconformities within an evolving foreland fold-thrust belt, Zagros Mountains. Journal of the Geological Society of London 158, 969-981.

Homke, S., Verges, J., Garces, M., Emami, H., Karpuz, R., 2004. Magnetostratigraphy of MiocenePliocene Zagros foreland deposits in the front of the Push-e Kush Arc (Lurestan Province, Iran). Earth and Planetary Science Letters 225, 397-410.

Hooghiemstra, H., Wijninga, V.M., Cleef, A.M., 2006. The palaeobotanical record of Colombia: implications for biogeography and biodiversity. Annals of the Missouri Botanical Garden 93, 297-324.

Hoorn, C.,Wesselingh, F.P., ter Steege,H., Bermudez,M.A.,Mora, A., Sevink, J., Sanmartín, I., SanchezMeseguer, A., Anderson, C.L., Figueiredo, J.P., Jaramillo, C., Riff, D., Negri, F.R., Hooghiemstra, H., Lundberg, J., Stadler, T., Särkinen, T., Antonelli, A., 2010. Amazonia through time: Andean uplift, climate change, landscape evolution, and biodiversity. Science 330, 927-931.

Hu, F.S., Hampe, A., Petit, R.J., 2008. Paleoecology meets genetics: deciphering past vegetational dynamics. Frontiers in Ecology and the Environment 7. doi:10.1890/070160.

Hughes, C., Eastwood, R., 2006. Island radiation on a continental scale: exceptional rates of plant diversification after uplift of the Andes. PNAS 103, 10334-10339.

Huntley, B., Birks, H.J.B., 1983. An Atlas of Past and Present Pollen Maps for Europe: 0-13,000 years ago. Cambridge University Press, Cambridge. (667 pp.).

Huntley, B., Webb III, T., 1989. Migration: species' response to climatic variations caused by changes in the earth's orbit. Journal of Biogeography 16, 5-19.

Jackson, S.T., Overpeck, J.T., 2000. Responses of plant populations and communities to environmental changes of the late Quaternary. Paleobiology 26 (Suppl. 4), 194-220. Jackson, S.T., Overpeck, J.T., Webb III, T., Keattch, S.E., Anderson, K.H., 1997. Mapped plant-macrofossil and pollen records of Late Quaternary vegetation change in eastern North America. Quaternary Science Reviews 16, 1-70.

Jackson, S.T., Betancourt, J.L., Lyford, M.E., Gray, S.T., Rylander, K.A., 2005. A 40,000-year record of vegetational and biogeographical dynamics in north-eastern Utah, USA. Journal of Biogeography 32, 1085-1106.

Janssens, S.B., Knox, E.B., Huysmans, S., Smets, E.F., Merckx, V.S.F.T., 2009. Rapidradiation of Impatiens (Balsaminaceae) during Pliocene and Pleistocene: result of a global climate change. Molecular Phylogenetics and Evolution 52, 806-824.

Jonsson, R., Dynesius, M., 2002. The fate of clades in a world of recurrent climatic change: Milankovitch oscillations and evolution. Annual Review Ecology System 33, 741-777.

Kadereit, J.W., Comes, H.P., 2004. The temporal course of alpine plant diversification in the Quaternary. In: Bakker, F.T., Chatrou, L.W., Gravendeel, B., Pelser, P.B. (Eds.), Plant species-level systematics: patterns, processes and new applications. Regnum Vegetabile, 143. Koeltz, Koenigstein.

Kadereit, J.W., Griebeler, E.M., Comes, H.P., 2004. Quaternary diversification in European alpine plants: pattern and process. Philosophical Transactions of the Royal Society of London. Series B 359, 265-274. 
Kelly, M., Buoncristiani, J.F., Schlüchter, C., 2004. A reconstruction of the last glacial maximum (LGM) icesurface geometry in the western Swiss Alps and contiguous Alpine region in Italy and France. Eclogae Geologicae Helvetiae 97, 57-75.

Klein, J.-C., 2001. La végétation altitudinale de l'Alborz Centrale (Iran), 2nd ed. Institut Français de Recherche en Iran, Tehran. (376 pp.).

Knapp, H.D., 1987. On the distribution of genus Cousinia (Compositae). Plant System Evolution 155, 1525.

Koçyigit, A., Yilmaz, A., Adamia, S., Kuloshvili, S., 2001. Neotectonics of East Anatolian Plateau (Turkey) and Lesser Caucasus: implication for transition from thrusting to strike-slip faulting. Geodinamica Acta 14, 177-195.

Kohn, M.J., Fremd, T.J., 2008. Miocene tectonics and climate forcing of biodiversity, western United States. Geology 36, 783-786.

Kuhle, M., 2008. The Pleistocene Glaciation (LGP and pre-LGP, pre-LGM) of SE Iranian mountains Exemplified by the Kuh-i-Jupar, Kuh-i-Lalezar and Kuh-i-Hezar Massifs in the Zagros. Polarforschung 77, 71-88.

Kürschner,H.,Djamali,M., 2008. Meesia Hedw. (Meesiaceae, Bryophyta) in Iran-evidence from a Quaternary subfossil record. Nova Hedwigia 87, 501-508.

Lemmon, E.M., Lemmon, A.R., Cannatella, D.C., 2007. Geological and climatic forces driving speciation in the continentally distributed trilling chorus frogs. Evolution 61-69, 2086-2103.

Léonard, J., 1981-1989. Contribution à l'étude de la flore et de la végétation des déserts d'Iran: etude des aires de distribution les phytochories, les chorotype. Fascicules, 1-9. Jardin botanique national de Belgique, Meise.

Léonard, J., 1993. Comparisons between the phytogeographical spectra of three Iranian deserts and those of various surrounding regions. Bulletin Jardin Botany National Belges 62, 389-396.

Leroy, S.A., Arpe, K., 2007. Glacial refugia for summer-green trees in Europe and south- west Asia as proposed by ECHAM3 time-slice atmospheric model simulations. Journal of Biogeography 34, 2115-2128.

Leroy, S.A., Dupont, L., 1994. Development of vegetation and continental aridity in northwestern Africa during the Late Pliocene: the pollen record of ODP Site. Palaeogeography Palaeoclimatology Palaeoecology 109, 295-316.

López-Vinyallonga, S., Mehregan, I., Garcia-Jacas, N., Tscherneva, O., Susanna, A., Kadereit, J.W., 2009. Phylogeny and evolution of the Arctium-Cousinia complex (Compositae, Cardueae-Caruinae). Taxon 58, 153-171.

López-Vinyallonga, S., Romashchenko, K., Susanna, A., Garcia-Jacas, N., 2011. Systematics of the Arctioid group: disentangling Arctium and Cousinia (Cardueae, Carduinae). Taxon 60, 539-554.

Magyari, E.K., Chapman, J.C., Gaydarska, B., Marinova, E., Deli, T., Huntley, J.P., Allen, J.R.M., Huntley, B., 2008. The 'oriental' component of the Balkan flora: evidence of presence on the Thracian Plain during the Weichselian late-glacial. Journal of Biogeography 35, 865-883.

Maslin, M., 2009. Quaternary climate transitions and cycles. In: Gornitz, V. (Ed.), Encyclopedia of Palaeoecology and Ancient Environments. Springer, Dordrecht, pp. 841-855.

McQuarrie, N., Stock, J.M., Verdel, C., Wernicke, B.P., 2003. Cenozoic evolution of Neotethys and implications for the causes of plate motions. Geophysical Research Letters 30 (SDE 6.1-SDE 6.4).

Médail, F., 2010. Biogeographical links between the Irano-Turanian and the Mediterranean floras: an introduction. XIII OPTIMA Meeting, Antalya.

Médail, F., Diadema, K., 2009. Glacial refugia influence plant diversity patterns in the Mediterranean Basin. Journal of Biogeography 36, 1333-1345.

Mehregan, I., 2008. Systematics, phylogeny and biogeography of Cousinia (Asteraceae). Unpublished $\mathrm{PhD}$ thesis, Johannes Gutenberg Universität, Mainz.

Mehregan, I., Kadereit, J.W., 2009. The role of hybridization in the evolution of Cousinia s. str. (Asteraceae, Cardueae). Willdenowia 39, 35-47.

Moore, P.D., Stevenson, A.G., 1982. Pollen studies in dry environmentswith particular reference to Turan. In: Spooner, B., Mani, H.S. (Eds.), Desertification and Development: Dry land Ecology in Social Perspective. Academic Press, London, pp. 249-268.

Moore, P.D., Webb, J.A., Collinson, M.E., 1991. Pollen Analysis. Blackwell Scientific Publications, Oxford. (16 pp.).

Mouthereau, F., Lacombe, O., accepted for publication. Building the Zagros collisional orogen: timing, strain distribution and the dynamics of Arabia/Eurasia plate convergence, Tectonophysics.

Noroozi, J., Akhani, H., Breckle, S.W., 2008. Biodiversity and phytogeography of the alpine flora of Iran. Biodiversity and Conservation 17, 493-521.

Ohlemüler, R., Anderson, B.J., Araújo, M.B., Butchart, S.H.M., Kudrna, O., Ridgely, R.S., Thomas, C.D., 2008. The coincidence of climatic and species rarity: high risk to small-range species from climate change. Biology Letters 4, 568-572.

Petit, R.J., Aguinagalde, I., de Beaulieu, J.-L., Bittkau, C., Brewer, S., Cheddadi, R., Ennos, R., Fineschi, S., Grivet, D., Lascoux, M., Mohanty, A., Müller-Starck, G., Demesure-Musch, B., Palmé, A., Martín, J.P., Rendell, S., Vendramin, G.G., 2003. Glacial refugia: hotspots but not melting pots of genetic diversity. Science 300, 1563-1565. 
Porter, S., 2004. Late Pleistocene glaciations of the Hindu Kush, Afghanistan. In: Ehlers, J., Gibbard, P.L. (Eds.), Quaternary glaciations extent and chronology; part III: South America, Asia, Africa, Australia, Antarctica. : Developments in Quaternary Science, 2. Elsevier, Amsterdam, pp. 1-2.

Qi, Y., Yang, Y., 1999. Topographic effect on spatial variation of plant diversity in California. Geography Information Science 1, 39-46.

R Development Core Team, 2010. R: A Language and Environment for Statistical Computing. R Foundation for Statistical Computing, Vienna, Austria. (3-900051-08-9) http://www.R-project.org.

Richardson, J.E., Pennington, R.T., Pennington, T.D., Hollingsworth, P.M., 2001. Rapid diversification of a species-rich genus of neotropical rain forest trees. Science $293,2242-2245$.

Rieseberg, L.H., Willis, J.H., 2007. Plant speciation. Science 317, 910-914.

Ritz, J.-F., Nazari, H., Salamati, R., Shafeii, A., Solaymani, S., Vernant, P., 2006. Active transtension inside Central Alborz: a new insight into the Northern Iran-Southern Caspian geodynamics. Geology 34, 477-480.

Rivas-Martínez, S., Sánchez-Mata, D., Costa, M., 1997. Syntaxonomical synopsis of the potential natural plant communities of North America I. Itinera Geobotanica 10, 5-148.

Saber, A., Attar, F., Djavadi, S.B., 2009. Studies of the pollen grains in the section Stenocephalae (Cousinia, Cass. Asteraceae) in Iran. Iran Journal of Botany 15, 114-128.

Schmitt, T., 2009. Biogeographical and evolutionary importance of the European high mountain systems. Frontiers Zoology 6 (Article number 9).

Schönswetter, P., Stehlik, I., Holderegger, R., Tribsch, A., 2005. Molecular evidence for glacial refugia of mountain plants in the European Alps. Molecular Ecology 14, 3547-3555.

Scotese, C.R., 2004. Cenozoic and Mesozoic paleogeography: changing terrestrial biogeographic pathways. In: Lomolino, M.V., Heaney, L.R. (Eds.), Frontiers of Biogeography: New Directions in the Geography of Nature. Sinauer Associates, Inc. Publishers, Sunderland, MA, pp. 9-26.

Şengör, A.M.C., Yılmaz, Y., 1981. Tethyan evolution of Turkey: a plate tectonic approach.Tectonophysics $75,181-241$.

Shabanian, E., Siame, L., Bellier, O., Benedetti, L., Abbassi, M.R., 2009. Quaternary slip rates along the northeast boundary of the Arabia-Eurasia collision zone (Kopeh Dagh Mountains, north-east Iran). Geophysical Journal International 178, 1055-1077.

Sherkati, S., Letouzey, J., 2004. Variation of structural style and basin evolution in the central Zagros (Izeh zone and Dezful Embayment), Iran. Marine and Petroleum Geology 21, 535-554.

Shtepa, I.S., 1976. Palynological investigation of the species of section Eriocousinia genus Cousinia Cass. (Compositae). Palynology in USSR-Papers of the Soviet palynologists to the international palynological conference (Lacnow, India). Publishing Office Nauka, Moscow (in Russian), pp. 3033.

Stebbins Jr., G.L., 1950. Variation and Evolution in Plants. Columbia University Press, New York. (643 pp.).

Stöcklin, J., 1974. Northern Iran: Alborz Mountains, in Mesozoic-Cenozoic orogenic belts: data for orogenic studies. Geological Society Special Publication 4, 213-234.

Stockmarr, J., 1971. Tablets with spores used in absolute pollen analysis. Pollen et Spores 13, 615-621.

Stoneley, R., 1981. The geology of the Kuh-e Dalneshin area of southern Iran, and its bearing on the evolution southern Tethys. Journal of the Royal Society London 138, 509-526.

Strömberg, C.A.E., Werdelin, L., Friis, E.M., Saraç, G., 2007. The spread of grass dominated habitats in Turkey and surrounding areas during the Cenozoic: phytolith evidence. Palaeogeography Palaeoclimatology Palaeoecology 250, 18-49.

Taberlet, P., Cheddadi, R., 2002. Quaternary refugia and persistence of biodiversity. Science 297, 20092010. 913

Thiel-Egenter, C., Gugerli, F., Alvarez, N., et al., 2008. Effects of species traits on the genetic diversity of high-mountain plants: a multi-species study across the Alps and the Carpathians. Global Ecology and Biogeography 18, 78-87.

Tzedakis, P.C., Lawson, I.T., Frogley, M.R., Hewitt, G.M., Preece, R.C., 2002. Buffered tree population changes in a Quaternary refugium: evolutionary implications. Science 297, 2044-2047.

Valente, L.M., Savolainen, V., Vargas, P., 2010. Unparalleled rates of species diversification in Europe. Proceedings of the Royal Society B 277, 1489-149.

van Zeist, W., Bottema, S., 1977. Palynological investigations in western Iran. Palaeohistoria 19, 19-85.

van Zeist, W., Woldring, H., 1978. A postglacial pollen diagram from Lake Van in east Anatolia. Review of Palaeobotany and Palynology 26, 249-276.

van Zeist, W., Timmers, R.W., Bottema, S., 1970. Studies of modern and Holocene pollen precipitation in southeastern Turkey. Palaeohistoria 14, 19-39.

Verdel, C., Wernicke, B.P., Ramezani, J., Hassanzadeh, J., Renne, P.R., Spell, T.L., 2007. Tertiary Cordilleran-style metamorphic core complexes in the Saghand region of central Iran. Geological Society of America Bulletin 119, 961-977.

von Hagen, K.B., Kadereit, J.W., 2001. The phylogeny of Gentianella (Gentianaceae) and its colonization of the southern hemisphere as revealed by nuclear and chloroplast DNA sequence variation. Organisms, Diversity and Evolution 1, 61-79.

White, F., Léonard, J., 1991. Phytogeographical links between Africa and Southwest Asia. Flora et Vegetatio Mundi 9, 229-246. 
Wick, L., Lemke, G., Sturm, M., 2003. Evidence of Lateglacial and Holocene climatic change and human impact in eastern Anatolia: high resolution pollen, charcoal, isotopic and geochemical records from the laminated sediments of Lake Van, Turkey. The Holocene 13, 665-675.

Willis, K.J., Niklas, K.J., 2004. The role of Quaternary environmental change in plant macroevolution: the exception or the rule? Philosophical Transactions of the Royal Society of London. Series B 359, 159-172.

Woldring, H., Bottema, S., 2001/2002. The vegetation history of east-central Anatolia in relation to archaeology: the Eski Acigöl pollen evidence compared with the Near Eastern environment. Palaeohistoria 43-44, 1-34.

Woodruff, F., Savin, S.M., 1989. Miocene deepwater oceanography. Paleoceanography 4, 87-140.

Wright, H.E., 1961. Pleistocene glaciation in Kurdistan. Eiszeitalter und Gegenwart 12, 131-164.

Wright, J.D., 2009. Cenozoic climate change, in: Encyclopedia of Palaeoecology and Ancient Environments (Ed.). Springer, Dordrecht, pp. 148-155.

Wright, H.E., McAndrews, J.H., van Zeist, W., 1967. Modern pollen rain in western Iran, and its relation to plant geography and Quaternary vegetational history. Journal of Ecology 55, 415-443.

Yilmaz, Y., 1993. New evidence and model on the evolution of the southeast Anatolian orogen. Geological Society of America Bulletin 105, 251-271.

Zachos, J., Pagani, M., Sloan, L., Thomas, E., Billups, K., 2001. Trends, rhythms, and aberrations in global climate $65 \mathrm{Ma}$ to Present. Science 292, 686-693.

Zhang,M.L., Uhink, C.H., Kadereit, J.W., 2007. Phylogeny and biogeography of Epimedium/ Vancouveria (Berberidaceae): Western North America-East Asian disjunctions, the origin of European mountain plant taxa, and East Asian Species diversity. Systematic Botany 32, 81-92.

Zohary, M., 1973. Geobotanical Foundations of the Middle East, 2. Fischer, Stuttgart. (739 pp.). 